\title{
Correction to: Simultaneous detection of periodontal pathogens in subgingival plaque and placenta of women with hypertension in pregnancy
}

\author{
P. Swati ${ }^{1} \cdot$ K. Ambika Devi ${ }^{2} \cdot$ Betsy Thomas ${ }^{1} \cdot$ Saadi Abdul Vahab $^{3} \cdot$ Satyamoorthy Kapaettu ${ }^{3} \cdot$ Pralhad Kushtagi $^{4}$
}

Published online: 22 January 2018

๑) Springer-Verlag GmbH Germany, part of Springer Nature 2018

\section{Correction to: Arch Gynecol Obstet (2012) 285:613-619 https://doi.org/10.1007/s00404-011-2012-9}

The original version of this article unfortunately contained a mistake. Ambika Devi K was not listed among the authors. The corrected authorship is given below

P. Swati · K. Ambika Devi · Betsy Thomas · Saadi Abdul Vahab $\cdot$ Satyamoorthy Kapaettu $\cdot$ Pralhad Kushtagi

The original article can be found online at https://doi.org/10.1007/ s00404-011-2012-9.

P. Swati

swatipralhad@gmail.com

K. Ambika Devi

ambika42000@yahoo.co.in

Betsy Thomas

betsythomas99@gmail.com

Satyamoorthy Kapaettu

ksatyamoorthy@manipal.edu

Pralhad Kushtagi

pralhadkushtagi@hotmail.com

1 Department of Obstetrics and Gynecology,

Chettinad Medical College and Research Institute,

Kelambakkam, Kanchipuram 603103, India

2 Department of Periodontics, Manipal College of Dental Sciences, Manipal 576104, India

3 Manipal Life Sciences Centre, Manipal University, Manipal 576104, India

4 Udupi District Maternity Hospital and Kasturba Medical College, Manipal, India 